\title{
Duchovní péče o nemocné a umírající v prvních učebnicích pastorální teologie (Rautenstrauch, Giftschütz, Chládek, Stach) ${ }^{1}$
}

\section{Zdeněk Duda}

Péče o nemocné a umírající, jež vždy nezávisle na teologických výkladech a společenských podmínkách patřila $\mathrm{k}$ základním úkolům praktické realizace křestanského života, prošla $\mathrm{v}$ souvislosti s celkovou změnou klimatu společnosti evropského Západu v druhé polovině 18. století výraznou proměnou. Nové zpo̊soby a postupy myšlení, v jejichž centru stál člověk a pojmy pokroku, osvěty a štěstí a jimž jsme si zvykli rríkat osvícenství, zasáhly všechny oblasti života společnosti, mezi jinými sociální, kulturní i náboženskou. Jistou přitažlivost našlo nové myšlení především u světských autorit, které se prostřednictvím takzvaně osvícenských reforem, často zaštítěných formulí obecného blaha, snažily posílit svou moc. V náboženské oblasti se jako inspirační zdroj vedle širokého pojmu osvícenství uplatnily i jansenistické a další ideje, jež společně přinesly nové pojetí zbožnosti a náboženského života vůbec.

Zbožnost a náboženské zacházení se smrtí také ovlivnily nové př́stupy ke smrti a požadavek nového kněžského působení na umírající a pozůstalé. ${ }^{2}$ Péče o nemocné a umírající dostala nové podněty a důrazy, byl vymezován a systematizován její ideální a závazný tvar. ${ }^{3}$ Dělo se tak mimo jiné v učebnicích pastorální teologie. ${ }^{4}$ Samotný obor pastorální teologie byl nově konstituovanou součástí kánonu teologických věd a novou univerzitní disciplínou. ${ }^{5}$

Cílem této studie je na základě rozboru prvních učebních textů oboru pastorální teologie a kontextu, $\mathrm{v}$ němž byly sepisovány, popsat základní východiska, postupy a podobu duchovní péče o nemocné a umírající, jež byla jako ideální a závazná v rámci univerzitní výuky prezentována budoucím katolickým duchovním správcům. ${ }^{6}$ Studie se opírá především o dva učební texty, jež v českém prostředí došly širšího využití. ${ }^{7}$ Výuka pastorální teologie se měla uskutečňovat $\mathrm{v}$ mateřském jazyce posluchačů, $\mathrm{v}$ našich zemích tedy $\mathrm{v}$ němčině a češtině. První jazykově českou učebnicí a jednou z prvních učebnic nového oboru vůbec byla kniha strahovského premonstráta Jiljího Chládka, jež byla pod názvem Počátkové opatrnosti

\footnotetext{
1 Práce vznikla v rámci projektu specifického výzkumu GAJU 096/2015/H - Pastorace nemocných a umírajících na konci 18. století.

2 Srov. Zdeněk R. NEŠPOR, Demonstrace konfesionality prostřednictvím pohřebních rituálů v českých zemích po vydání Tolerančního patentu, in: Církev a smrt. Institucionalizace smrti v raném novověku, ed. Martin HOLÝ - Jiř́ MIKULEC, Praha: Historický ústav, 2007, s. 286.

3 K dějinám pastorace nemocných srov. např. Gottfried ROTH - Hansjörg SCHILD, Das Phänomen der Krankheit und der Kranken in der Kirche, in: Handbuch der Pastoraltheologie, Bd. 4, Freiburg: Herder, 1969, s. 178-193;

4 Srov. Zdeněk DUDA, Nemoc a smrt v opatrné péči osvícenského pastýře. K dějinám pastorace nemocných a umírajících na konci 18. století optikou první české učebnice pastorální teologie, in: Jednota v mnobosti - Olomouc 2014, Fórum Velehrad X., Olomouc: Refugium, 2015, s. 59-66.

5 Srov. Alois KŘIŠŤAN, Počátky pastorální teologie v českých zemích, Praha: Triton, 2004. Dále srov. Zdeněk DUDA, Historiografický obraz počátků (české) pastorální teologie a jejího dalšího směřování v 19. století, in: Církve 19. a 20. století ve slovenské a české bistoriografii, ed. Pavol MAČALA - Pavel MAREK - Jiří HANUŠ, Brno: Centrum pro studium demokracie a kultury, 2010, s. 18-20. 6 Závazná tabelární osnova nového oboru pastorální teologie pracovala s pojmem duchovní péče o nemocné, další zde analyzované texty s pojmem navštěvování nemocných.

7 Srov. Kamil ČINÁTL, Katolické osvícenství a koncept pastorální teologie, Kuděj 2/2000, s. 31.
} 
pastýřské vydána $\mathrm{v}$ Praze $\mathrm{v}$ letech $1780-1781 .^{8}$ Druhým a podobně zde analyzovaným textem byl český překlad dobově nejúspěšnější a oficiálně předepsané učebnice vídeňského pastorálního teologa Franze Giftschütze, ${ }^{9}$ již do češtiny z druhého vydání z roku 1787 pod názvem Počátkové pastýřské teologie převedl olomoucký profesor Václav Stach. ${ }^{10}$

\section{Reforma teologického studia a závazná osnova nové disciplíny pastorální teologie}

Prvníučebnítexty nového oboru pastorálníteologie byly sepisovány podle tabelárnípředlohy této disciplíny (1778), zamýšlené jako systematické pojednání a uvedení do praktického výkonu duchovenského povolání. Předloha, jejímž autorem byl tvůrce nové koncepce teologického studia břevnovský opat František Štěpán Rautenstrauch, ${ }^{11}$ byla stvrzena silou dvorských dekretů. Stala se tak závaznou normou. ${ }^{12}$ Zásah státu nebyl náhodný, během druhé poloviny 18. století si osvícenští monarchové nárokovali stále větší vliv na přípravu budoucích duchovních.

$\mathrm{K}$ zásadní reformě teologického studia došlo $\mathrm{v}$ podunajské monarchii v polovině 70 . let 18. století. Reforma provedená vjansenisticko-osvícenském duchu měla pragmatické zacílení, silně orientované na praxi. Vycházela také vstříc dobovým požadavkům po systematizaci, jednotlivým oblastem teologického myšlení byl vtisknut nový řád a místo. Teologie a příprava duchovních byla podřízena praktickému pastoračnímu úmyslu. ${ }^{13}$ Budoucí kněží byli připravováni na roli správců duchovenského úřadu, předmětem jejich činnosti se měla stát správa a naplnění tř́ hlavních úréedních povinností. Jejich úkolem bylo poučovat, posvěcovat a podporovat zbožnost. $K$ prrípravě na řádný výkon těchto povinností sloužila především právě nově zavedená disciplína pastorální teologie.

Závazná osnova nového předmětu, jež byla následně rozvedena a konkretizována $\mathrm{v}$ nově vytvářených učebních textech prakticky orientovaného oboru, pracovala s pojmem kněžství, u něhož bylo znatelně zeslabeno př́mé pouto $k$ nadpřirozenému Zjevení. Sestávalo naopak

8 Jiljí (Aegidius) Chládek (1743-1806) byl premonstrátským řeholním kanovníkem, od roku 1778 profesorem české pastorálky na pražské teologické fakultě. Zastával také funkci děkana (1792-1793) a rektora univerzity (1794) a působil i jako cenzor náboženské literatury. Srov. Jiljí CHLÁDEK, Počátkové opatrnosti pastýřské aneb krátká naučení, jak by se pastýrové duchovní v povolání svém chovati mèli, I-III, Praha, 1780-1781.

9 Franz Giftschütz (1748-1788) působil nejprve jako duchovní u sv. Štěpána ve Vídni, v roce 1778 se stal profesorem pastorální teologie na vídeňské teologické fakultě. Jeho učebnice pastorální teologie Leitfaden für die in den k.k. Erblanden vorgeschriebenen deutschen Vorlesungen über die Pastoraltheologie byla ve své době nejúspěšnějším učebním textem svého oboru. Tištěna byla v pěti vydáních $(1785,1787,1796,1801,1811)$, přeložena byla také do latiny a češtiny.

10 Václav Stach (1754-1831) působil jako profesor pastorální teologie v generálním i biskupském semináŕi v Olomouci, v roce 1799 byl penzionován. Bývá uváděn jako představitel lidovýchovných snah v duchu josefínského osvícenství i v souvislosti s počátky novočeské poezie. V roce 1787 vydal známou Př́rucku učitele lidu. Srov. Franz GIFTSCHÜTZ, Počátkovék veřejnému v cís. král. zemích préedepsanému vykládání pastýř́ské teologie, I-II, Praha, 1789-1790.

11 František Štěpán Rautenstrauch (1734-1785) byl od roku 1773 opatem dvojopatství Broumov-Břevnov a také ředitelem teologické fakulty v Praze, později ve Vídni. Byl silně ovlivněn jansenisticko-osvícenským myšlením, patřil k přesvědčeným proponentům (josefínských) reforem. V roce 1782 byl jmenován dvorním radou při Česko-rakouské dvorské kanceláři a členem duchovní dvorské komise. Patřil do okruhu nejbližších rádců panovníka. Navrhl a prosadil reformu bohosloveckého studia. Byl také pověřen založením biskupských generálních seminářư.

12 Rautenstrauchův Tabellarischer Grundriß der in der deutscher Sprache vorzutragenden Pastoraltheologie je uveden a rozepsán např́klad ve sborníku Wege der Pastoraltbeologie: Texte einer Bewusstwerdung. I. 18. Jabrbundert: Grundlegung und Entfaltung, ed. Anton ZOTTL - Werner SCHNEIDER, Eichstätt: Franz Sales Verlag, 1987, s. 27-34. K tomu srov. český překlad Alois KŘIŠŤAN, Počattey, s. 54-62.

13 Srov. Josef MÜLLER, Zu den theologiegeschichtlichen Grundlagen der Studienreform Rautenstrauchs, Tübinger Theologische Quartalschrift 146/1966, s. 62-64. 
z obsahů, jež souvisely s aktivitami zaměřenými do tohoto světa a týkaly se výchovy, mravů a obecného blaha. Duchovní byl nyní mnohem spíše než jako tridentský ideál zbožného andělského kněze obětníka vnímán jako osoba dvojí funkce, zásadně jako služebník církve a odvozeně jako služebník státu, úředník zavázaný pracovat na poli spásy, státní správy a světu imanentního štěstí. ${ }^{14}$

Kněz jako duchovní správce byl jediným subjektem této (duchovenské) správy, jedinou osobou oprávněnou jednat a řešit otázku pastorace. Obsahem pastorační práce byla výuka, napomínání, trestání, těšení, udílení svátostí a budování farního společenství. Pastorační práce byla jednosměrná, vedla od úřadu duchovního správce $\mathrm{k}$ jednotlivým farníkům i k celé farní obci. Subjektem jednání a jediným aktérem na poli pastorace byl duchovní správce; laici a farní obec byli předmětem odpovídající poučené péče.

Tabelární předloha nové disciplíny dělila předmět výuky do čtyř větších celků. Na první, úvodní část, jež přinášela přehled základních termínů včetně pastoračního úřadu a pastorální teologie, navazovaly tř́i tematické okruhy odpovídající třem hlavním povinnostem duchovního pastýře. Péče o nemocné a umírající byla zařazena v oddíle o povinnosti správy a vysluhování svátostí.

Podobně jako dvěma dalším hlavním povinnostem správce duchovenského úřadu byl i povinnosti správy a vysluhování svátostí připsán biblický základ. Odkazováno bylo na slova poslání (Mt 28,19-20). Ta se sice př́mo týkala křtu, přeneseně však měla zahrnout i ostatní svátosti. Pojednání tematizující povinnost správy a vysluhování svátostí mělo být v prřistích učebnicích strukturováno podle počtu svátostí do sedmi částí. Přitom si mělo všímat pouze vlastního udělování svátostí, věroučná složka náležela dogmatice, učení o požadavcích kladených na př́ijemce svátostí teoretické morálce. Samostatně pro každou část měly být uvedeny tři shodné okruhy, týkající se př́ijemců svátostí, jejich př́pravy a obřadů a obyčejů při vysluhování. Oporou zde přitom byl rituál př́slušného biskupství, jemuž měla být přizpůsobena nauka o obřadech a obyčejích.

Zvláště bylo upozorněno na tři takzvaně nejdůležitější a nejtěžší materie, které přicházely na pořad při zpracování tématu svátosti pokání, posledního pomazání a manželství. Konkrétně tím bylo myšleno učení o zpovědnici a třech úřadech zpovědníka (soudce, učitele a lékaře duší), „nejvýše důležitá duchovní péče o nemocné“ a praktické otázky spojené s uzavíráním manželství (překážky, neplatnost, revalidace, dispenze). ${ }^{15}$ Závěr části věnované povinnosti správy a vysluhování svátostí měl být ještě věnován pojednání o modlitbě a svaté mešní oběti duchovního správce za svěřenou obec.

14 Srov. Rudolf ZUBER, Osudy moravské církve v 18. století, II. díl, Olomouc: Matice cyrilometodějská, 2003, zvláště s. 85; $150-152$. K reformě teologického studia, dobovému pojmu kněžství i kontextu dobové teologie vedle citovaného díla dále srov. Hedvika KUCHAŘOVÁ - Zdeněk R. NEŠPOR, Pastor bonus, seu idea (semper) reformanda. Vzdělávání a výchova kléru pro působení ve farní správě v českých zemích v 18. a na počátku 19. století, Český časopis bistorický 2/2007, s. 351-392; Konrad BAUMGARTNER, Der Wandel des Priesterbildes. Beiträge zur pastoraltheologischen Literatur vor Allem des 17. und 18. Jahrhunderts, in: Pastoraltheologie: Ein entscheidender Teil der josepbinischen Studienreform: Ein Beitrag zur Geschichte der praktischen Theologie, ed. Ferdinand KLOSTERMANN - Josef MÜLLER, Wien: Herder, 1979, s. 174-186; Zdeněk DUDA, Obraz katolickébo duchouníbo v proních učebnicích pastorální teologie (Giftschütr, Cbládek, Stach), v tisku.

15 Srov. „Při svátosti posledního pomazání musí být učena celá praxe nejvýše důležité duchovní péče o nemocné. Také chování pastýře k odsouzeným zločincům je zde zvlášt dưležité přednášet." Citováno podle českého překladu Alois KŘIŠŤAN, Počátky, s. 59. 
Z návrhu osnovy předmětu pastorální teologie je zřejmé, že pastoraci nemocných a umírajících přikládal její tvůrce značný význam. Dobově se navíc jednalo o novinku. Pojem nemoci nabyl pod vlivem medikalizačních procesů a jansenisticko-osvícenských snah na významu, stal se místem, kde se ještě dalo operovat s pozemským štěstím a současně myslit na štěstí věčné. Duchovní péče o nemocné nahradila, obsadila a přeznačila tradiční křestanskou přípravu na dobrou smrt. Opat Rautenstrauch ji považoval za jednu z nejobtížnějších a přitom nejdůležitějších oblastí prakticky zaměřených aktivit duchovního pastýře. Doporučoval o ní pojednat v části věnované svátostné praxi církve, i když si byl vědom, že se jednalo o mnohem širší oblast. Obdobně tomu bylo i u péče o odsouzené osoby, jíž se pozornosti mělo dostat také na tomto místě a pro niž také platilo, že vysluhování svátostí představuje jen její malou část.

Dokladem důležitosti přisuzované $\mathrm{v}$ této době duchovní péči o nemocné byla i skutečnost, že promluva duchovního pastýře u lůžka nemocného byla vedle dalších praktických znalostí a dovedností, zásadně přednesu kázání a vyučování katechismu, součástí farní konkurzní zkoušky, kterou museli na základě nařízení z ledna 1782 a poté řady dalších dvorských dekretů projít všichni, kdo žádali o nějakou farnost. ${ }^{16}$

\section{Pozice a východiska duchovní péče o nemocné a umírající v učebnicích Jiljího Chládka a Franze Giftschütze}

Z Rautenstrauchovy tabelární předlohy vycházely všechny chystané učební texty. Osnova představovala závazný rámec, konkrétní náplň a obsahy však bylo možné uchopit tvůrčím způsobem. $V$ učebnicích se také různou měrou odrazily další potřeby a přání státní moci. Vzorovou v tomto ohledu byla učebnice vídeňského pastoralisty Franze Giftschütze, která ve svém druhém vydání odkazovala na téměř dvě stě (174) státních nařízení. ${ }^{17}$ Tato skutečnost byla také důvodem jejího značného úspěchu a oblíbenosti u dvora. Již v prvním vydání byla předepsána jako všeobecná a závazná učebnice pro výuku pastorální teologie v celé monarchii.V tomto postaveníji nahradil až roku 1812 učební text Andrease Reichenbergera. ${ }^{18}$ Rautenstrauchovu předlohu pochopitelně následovaly i obě „české" učebnice, Stachův překlad úspěšných Giftschützových Leitfaden i původní učební text Jiljího Chládka.

Chládkova učebnice byla strukturována v souladu s doporučenou osnovou. Vyznívala velmi kriticky vůči dosavadní církevní praxi. V prvním dílu byly stručně nastíněny dějiny pastorální teologie, zmíněni byli i čeští kazatelé, jistých sympatií se dostalo českým bratř́m. Následně byla pojednána tematika vyučování, obecné zásady, homiletika, soukromé vyučování. Důraz byl kladen na individuální působení duchovních správců na lidi ve farnosti a na metodu rozhovoru. Vyjadřován byl tolerantní přistup $\mathrm{k}$ jinověrcům i nevěŕícím. V druhém dílu věnovaném tématu udílení svátostí bylo vyzdvihnuto pokání jako jediný zdroj nápravy

16 Faráři, kteří se zvláště osvědčili v takzvaném úřadu duchovní správy a mohli to doložit potvrzením, mohli být navrženi na jinou faru bez farní konkurzní zkoušky. Promluvu duchovního správce u lůžka nemocného jako součást zkoušky nařizoval dekret z 9. února 1784. Srov. Eduard WINTER, Josefinismus a jeho dějiny. Příspěvky k duchouním dějinám Čech a Moravy 1740-1848, Praha: Nakladatelství Jelínek, 1945, s. 132-133.

17 Srov. Gustav PIRICH, Franz Giftschütz (1748-1788) - der erste Wiener Pastoraltheologe. Theologische Grundlinien in Leben und Werk unter dem Einfluß des Jansenismus, der katbolischen Aufklärung und des Ultramontanismus, Würzburg: Seelsorge/Echter, 1992, s. $172-173$. 18 Srov. tamtéž, s. 132-134. 
hříšníka, kriticky byl přitom nahlížen institut odpustků a také jezuitské zpovědní praktiky. Tématem třetího dílu byl př́kladný život pastýřů, jednalo se asi o nejkritičtější část učebnice. Kněz zde vystupoval nejen jako odborník na náboženský a duchovní život, ale také jako garant právního bezpečí a jistoty lidí ve své farnosti, např́k lad jako advokát poddaných vưči bezpráví ze strany vrchnosti. ${ }^{19}$ Chládek duchovního nahlížel jako dobrého pastýře, učitele mravnosti. Př́iznačný byl v tomto ohledu výjev na titulní straně jeho učebnice, kde dobrý pastýř nalézal ztracenou ovci.

Dvorským dekretem z listopadu roku 1780 byl Chládkův spis přijat jako vysokoškolská učebnice. Předepsán byl pro Prahu a Brno. Již od počátku se stal předmětem ostré kritiky a odmítání. $\mathrm{Na}$ autora učebnice se snesly výtky a urážky, viněn byl ze zrady kněžského stavu, podezírán z kacířství. Chládkův text prý při svých přednáškách před inspekcí dvorské komise zesměšňoval olomoucký profesor Václav Stach a díky tomu měl být pověren překladem u dvora oblíbené učebnice Giftschützovy. ${ }^{20} \mathrm{Ta}$ ovšem byla v mnohém radikálnější a důslednější, v jistém smyslu lépe a racionálněji strukturovaná. V josefínském duchu také nahlížela na duchovního jako úředníka státu, jenž měl mít v péčivěci náboženské, podporující obecné blaho. Morální nauku výslovně představovala jako hlavní obsah evangelijní zvěsti, věroučná nařízení vnímala jen jako doprovodný přívazek. ${ }^{21}$ Téma spásy jako věčného štěstí propojovala se štěstím pozemským a podřizovala je požadavku mravního života; téměř se až stalo funkcí morálky. Stachův překlad, tištěný pod názvem Počátkovépastýřrkét teologie v Praze v letech 1789-1790, záhy nahradil učebnici Chládkovu. ${ }^{22}$

Péče o nemocné a umírající byla v Chládkově učebnici dle Rautenstrauchových intencí zasazena do kontextu svátostné praxe církve a pojednána $\mathrm{v}$ šesté kapitole druhého dílu nazvané $O$ svátosti posledníbo pomazání. Kapitola byla rozdělena do tří částí. První a nejrozsáhlejší byla věnována navštěvování a zaopatřování nemocných, druhá si stručně všímala svátosti posledního pomazání a $\mathrm{v}$ třetí závěrečné části byl navržen způsob, jak se mělo zacházet s osobami odsouzenými $\mathrm{k}$ smrti. ${ }^{23}$ Udělení svátosti posledního pomazání, respektive tř́i posledních svátostí, dříve hlavní náplň tradiční křestanské prŕpravy na dobrou smrt, jak o tom například svědčí bohatá literatura knih artes moriendi, byla i zde jen součástí širši duchovní péče o nemocné. A protože i sebelehčí nemoc se v této době ještě téměř vždy mohla obrátit ke smrti, byla také samozřejmě součástí péče o umírající.

Stachova, respektive Giftschützova, učebnice vztah mezi svátostnou praxí církve a duchovní péćí o nemocné dále rozvolnila. Udělení svátosti posledního pomazání jako by ani nebylo (nutnou) součástí této péče. Giftschütz se nedržel Rautenstrauchových doporučení a o duchovní péči o nemocné pojednal již v třetí části prvního dílu své učebnice. ${ }^{24}$ Zařadil ji do kapitoly věnované soukromému vyučování, jímž byla myšlena úloha duchovního

19 Srov. Jan HARVILKO, Jiljí Chládek a jeho počátkové opatrnosti pastýřské, Theologická revue 1-4/2006, s. $382-383$.

20 Srov. Alois KŘIŠŤAN, Počátky, s. 92 a dále František CINEK, K národnímu probužení moravskébo dorostu kněžskébo 1778-1870,

Olomouc: Družina literární a umělecká, 1934, s. 71-72.

21 Srov. Franz GIFTSCHÜTZ, Leitfaden für die in den k.k. Erblanden vorgeschriebenen deutschen Vorlesungen über die Pastoraltheologie,

Wien, 1787, s. 35.

22 Srov. Alois KŘIŠŤAN, Počátky, s. 92.

23 Srov. Jiljí CHLÁDEK, Počátkové, II. díl, s. 152-203.

24 Srov. Franz GIFTSCHÜTZ, Počátkové, I. díl, s. 233-256. 
správce dbát o to, aby se každý z farníků mohl podle svých potřeb, stavu a možností seznámit $s$ křestanským učením a toto učení $s$ prospěchem využít ve svém životě. ${ }^{25}$

V duchovní péči o nemocné viděl autor učebnice především pomoc osobám, jež se nalézaly ve zvláštní situaci a jimž bylo třeba poskytnout potřebnou a stavu odpovídající útěchu a ponaučení. Podobné zvláštní privátní péče se vedle nemocných mělo dostat i snoubencům a dalším. Duchovní pastýř měl svou radou a př́kladem sloužit všem lidem ve své farnosti a nezanedbat jedinou př́ležitost, kdy by mohl být prospěšný. Takovou př́ležitostí byla i nemoc a s ní spojené obtíže a odtud plynula povinnost duchovních pastýřů navštěvovat nemocné. Cíle duchovní péče o nemocné odpovídaly cílům (soukromého) vyučování, jež mělo přispět $\mathrm{k}$ poučení a polepšení dotčených a obecně $\mathrm{k}$ rozmnožení a posílení štěstí svěřeného lidu. ${ }^{26}$

Giftschützův př́istup k péči o nemocné a umírající byl silně pragmatický a počítal s prakticky zacílenou zbožností. Veškeré jednání mělo být zbavené pověr a neúčelných a nesmyslných zvyků a obyčejů a mít logické a racionální zdůvodnění. Přitom však měl na mysli dobro člověka. Oním člověkem však byl, ostatně obdobně tomu bylo i u Chládka, člověk s nekonkrétní tváríi, poslušný a vděčný objekt poučené péče. Cíl této péče byl výchozím bodem, obsahy byly závislou proměnnou osvícenského pojmu štěstí a státní správy a (náboženská) argumentace uzavřenou skládačkou. Do logicky uspořádaného systému k potvrzení již hotových náhledů a požadovaných vzorců jednání byla doplňována vhodná zdůvodnění, často ve formě biblických citátů. ${ }^{27}$ To byl ale nejen tenkrát tradiční a obvyklý způsob.

\section{(Svátostný) obyčej posledního pomazání}

V druhém dílu Giftschützovy učebnice, v části věnované svátostné praxi církve, byli budoucí duchovní správci seznamováni s tím, že v katolické církvi se s odkazem na Jakubovu epištolu (Jak 5,14 ) vyskytuje obyčej vykonávání modliteb nad těžce nemocnými, s nimiž je spojeno několikeré pomazání. Tomuto obyčeji se mělo ř́kat pomazání nemocných nebo také poslední pomazání. ${ }^{28}$ Praxe církve při této aktivitě následovala biblický př́klad. Giftschütz ji jen formálně přiřadil $\mathrm{k}$ vysluhování svátostí, termínu svátost však záměrně nepoužil. Zdrženlivý postoj zachoval i překladatel Václav Stach, i on se vyhnul pojmu svátost. ${ }^{29}$

Pro konkrétní průběh a podobu vysluhování tohoto „obyčeje“ autor učebnice ve všem odkazoval studenty bohosloví na odpovídající (vídeňský) diecézní rituál, z něhož v poznámkách bohatě citoval. $Z$ toho je patrné, že tomuto „obyčeji“ nepřikládal nějaký zvláštní význam. Otázku vysluhování podřídil stávající církevní tradici, dogmatickou ponechal stranou. Dotkl se pouze několika otázek, př́jemců pomazání a jejich př́pravy, jak to požadovala závazná předloha. Výslovně se zmínil, že toto pomazání je pouze pro nemocné, mezi něž počítal i velmi staré lidi, kteří žádnou bezprostřední nemocí netrpěli.

25 Srov. tamtéž, s. 182.

26 Srov. tamtéž, s. 184.

27 K užívání biblických citátů v učebnici vídeňského pastoralisty srov. Gustav PIRICH, Franz Giftschütz, s. 196.

28 Srov. Franz GIFTSCHÜTZ, Leitfaden, s. 161-164.

29 Srov. Franz GIFTSCHÜTZ, Počátkové, II. díl, s. 144-147. 
Dostatečnou „kvalifikací“ zde byl velmi sešlý věk. Naproti tomu uvedl kategorie těch, kdo pomazání přijímat nemohli, vždy s př́ślušným odkazem na vídeňský rituál. ${ }^{30}$

Př́slušnému diecéznímu rituálu také byla přenechána otázka, zda poslední pomazání udělovat před, nebo po „prrijímání Večeře Páně“ ${ }^{31}$ Chládek se této problematiky nedotýkal, pořádek jednotlivých svátostí uváděl zcela samozrejmě, stejně jako pojem svátost. Po zpovědi mělo následovat přijímání eucharistie a $\mathrm{v}$ př́padě potřeby i svátost posledního pomazání, případně i udělení plnomocných odpustků (generální absoluce) podle nařízení arcibiskupské kanceláře z února $1750 .{ }^{32}$

Příznačné je, že pastoralista Giftschütz nepropojil vysluhování „obyčeje“ posledního pomazání $s$ duchovní péčí o nemocné. Společná jednotlivým ustanovením uvedeným v prvním a druhém díle učebnice byla jen snaha, aby duchovní pastýř přicházející za nemocným nebyl vnímán jako posel smrti. V této pozici nemohl odpovídajícím způsobem pečovat o nemocné, ani udělit poslední pomazání. Náboženské obřady měly mít větší účinek, když jim přijímající jako objekt poučené péče mohl dobře porozumět a vnímat jejich smysl. Z praktických důvodů měli tedy duchovní pastýři při každé př́ležitosti poučovat farníky o své úloze ve farní obci. ${ }^{33}$ Podobné doporučení, stejně jako tehdy již tradiční kritika odkládání návštěvy kněze u lůžka nemocného až do hodinky smrti, se objevuje i u Chládka. ${ }^{34}$

\section{Podoby a cíle duchovní péče o nemocné a umírající}

Duchovní péče o nemocné se v Giftschützově učebnici v duchu osvícenského antropocentrismu zakládala na diferencovaném a individualizovaném př́stupu $\mathrm{k}$ nemocným. ${ }^{35}$ Cíle zůstávaly shodné, konkrétní podoba se ale lišila podle sociální př́íslušnosti, náboženství a druhu nemoci. Péče vycházela z potřeb, stavu a možností nemocného, na duchovní správce kladla nároky dobře znát své farníky a umět s nimi dobře a slušně komunikovat, získat si jejich důvěru. Duchovní správce měl vzít do úvahy věk, společenské postavení, majetek, rodinné vztahy, náboženské přesvědčení a znalost a zachovávání křestanské morálky, také vážnost nemoci. Podle toho měl poznat, jak s různými druhy nemocných nejlépe jednat, jak jim být nejvíce prospěšný. To vyžadovalo poskytnout jim odpovídající potěchu a ponaučení, napomenutí a nápravu. To vše při rozhovorech a návštěvách. Duchovní péče o nemocné při absenci svátostného rozměru znamenala především vlastní navštěvování nemocných. ${ }^{36}$ Obecně měla duchovní péče o nemocné shodné cíle jako veškeré aktivity duchovního správce, totiž upokojení a polepšení nemocného. ${ }^{37}$ Konkrétně to znamenalo jednak

\footnotetext{
30 Srov. tamtéž, s. 146.

31 Podle toho, zda bylo pomazání nemocných udělováno před, nebo po přijímání eucharistie, se lišila struktura a podoba modliteb a jednotlivých částí tohoto pomazání. V Římském rituálu z roku 1614 (Rituale Romanum) bylo pomazání nemocných řazené jako poslední ze tří posledních svátostí, a stalo se tak v plném smyslu slova pomazáním posledním. Srov. Benedikt KRANEMANN, Die Krankensalbung in der Zeit der Aufklärung. Ritualien und pastoralliturgische Studien im deutschen Sprachgebiet, Münster: Aschendorffsche Verlagsbuchhandlung, 1990, s. 126-133.

32 Srov. Jiljí CHLÁDEK, Počátkové, II. dúl, s. 164-171. Dále srov. Eduard BRYNYCH, Generální absoluce umírajících čili Požehnání apoštolské v dobu smrti, Časopis katolickébo duchovenstva 8/1880, s. 582-595.

33 Srov. Franz GIFTSCHÜTZ, Počátkové, I. díl, s. 233, 239; II. díl, s. 145.

34 Srov. Jiljí CHLÁDEK, Počátkové, II. díl, s. 153-154.

35 Podobně rozrůzněna byla i celá oblast soukromého vyučování. Srov. Franz GIFTSCHÜTZ, Počátkové, I. díl, s. 230.

36 Jedním dechem zde bylo v duchu Rautenstrauchova náhledu opakováno, že navštěvování nemocných je jednou z nejdůležitějších a také nejobtížnějších aktivit úřadu duchovního pastýře. Srov. tamtéž, s. 233.

37 Srov. tamtéž, s. 22.
} 
uklidnit nemocného a povzbudit ho k trpělivosti a odevzdání se do vůle Boží, jednak využít stav nemoci k změnění jeho mysli, polepšení a přípravě na budoucí život. U jednotlivých kategorií nemocných osob však bylo nutné volit odlišná slova a obsahy, jak těchto cílů dosáhnout. $\mathrm{V}$ př́padě vážné nemoci bylo cílem duchovní péče připravit umírajícího na útěšné a pokojné očekávání smrti. ${ }^{38}$ Duchovní péče o nemocné mohla také znamenat úsilí o uzdravení, to ale jen v zcela omezených př́ípadech. Duchovní správce typicky nebyl odborníkem na lékařskou stránku, měl se spíše držet stranou a vyhnout se prŕpadným mrzutostem, pomluvám a třenicím $s$ lékaři. Jako všeobecný př́tel lidu měl ale zasáhnout tam, kde se lékaře nedostávalo. Argumentem zde byl biblický obraz Krista, který leckdy dřive uzdravil tělo a teprve pak duši. ${ }^{39}$

Uzdravení také nezáviselo jen na lékařských znalostech a dovednostech, bylo darem, milostí Boží. Nejen v nemoci se člověk měl naučit, že všechno, co má, pochází od Boha a je mu poskytnuto darem. Taková znalost vyžadovala postoj vděčnosti a aktivní spolupráce při službě Bohu, lidem a obecnému dobru. ${ }^{40}$ Teologický pojem milosti jako nezaslouženého daru božské lásky a milosrdenství se u Giftschütze objevoval zcela běžně. ${ }^{41}$

Diferencovaný př́stup $\mathrm{k}$ nemocným se odrážel i v jasně odměřeném poměru $\mathrm{k}$ (tradiční) literatuře určené nemocným osobám. Obsah takových knih byl mnohdy pro osvícené katolické učence problematický, často odpovídal odlišnému a odmítanému pojetí zbožnosti, což bylo velmi zřetelně vidět u témat, která úzce souvisela se smrtí. Autor učebnice se zvláště vyslovil k modlitbám, jež literatura pro nemocné obsahovala. Ty měly být bud' velmi obecné, nebo naopak př́liš úzce zaměřené, což pochopitelně nevyhovovalo individualizovanému přistupu $\mathrm{k}$ nemocným a vyvolávalo spíše obtíže a těžkosti. Zásadnějším důvodem ovšem byla skutečnost, že sebelepší zbožný text nemohl obsáhnout všechny nároky kladené na duchovní péči o nemocné. ${ }^{42}$

Modlitbě přitom vídeňský pastoralista přikládal značný význam. Viděl v ní praktický prostř̌edek k posilování ctnostného života a přeneseně i $\mathrm{k}$ dosažení věčného štěstí. Modlitba měla člověka upomínat na jeho původ a z něho vyplývající podřizenost božské i lidské moci. Člověka také měla odvádět od toho, aby se přespř́liš zabýval sám sebou, at už motivem takového jednání byla pýcha nebo nadměrný smutek a malomyslnost. Modlitba měla také člověku pomoci ve chvílích, kdy se mu již dostalo poučení a padala na něj slabost. Vkaždém případě měla vycházet ze situace konkrétního člověka, reflektovat jeho specifika a obracet se přímo k Bohu. Modlit se mohl člověk sám, společně s jinými nebo také společně se svým duchovním pastýřem. Modlit se mohl také za druhé, typicky za nemocné a umírající. Při společné modlitbě s nemocným měl pastýř dbát na to, aby modlitba byla vedle výše uvedených charakteristik krátká a srozumitelná. ${ }^{43}$

38 Srov. tamtéž, s. 234.

39 Podobně bylo argumentováno i u otázky př́tomnosti duchovního správce při operaci nemocného, která tehdy byla vždy úzce spojena s nebezpečím smrti. Přítomnost duchovního správce byla v této záležitosti zbytečná, případně neslušná, nebyl v této věci odborníkem. Pokud si to ale nemocný přál, měl mu duchovní pastýŕ vyhovět. Svoji úlohu jinak duchovní pastýŕ naplnil již jen tím, že nemocného na operaci, respektive na př́padnou smrt, dobře připravil a dodal mu potřebné odvahy. Srov. tamtéž, s. 234-235; 256.

40 Srov. tamtéž, s. 231.

41 Srov. Gustav PIRICH, Franz Giftschütz, s. 197-198.

42 Srov. Franz GIFTSCHÜTZ, Počátkové, I. díl, s. 238.

43 Společná modlitba duchovního pastýře s umírajícím měla končit prosbou jednak o Boží pomoc a uzdravení, jednak o trpělivost, naději a odevzdání se do rukou a vůle Boží. Srov. tamtéž, s. 196-197; 224-225; 238. 
Modlitba měla mít praktické zacílení. Měla např́klad pomoci umírajícímu poručit svou duši Bohu. Nebyl-li již umírající při smyslech, bylo zbytečné již v takové modlitbě pokračovat. Přesto si to mnohdy blízcí žádali. Z praktických důvodů bylo nutné i vhodné vyhovět. Duchovní pastýř mohl takovou pŕíležitost využít k poučení právě těchto osob. Podobného poučení při modlitbě se jim mělo dostat, když se jejich stav změnil na pozůstalé. ${ }^{44} \mathrm{Za}$ takto nahlíženým pojmem modlitby je třeba vidět kontext dobového teologického myšlení i Giftschützovu snahu o propojení pojmu věčného štěstí s pojmem štěstí pozemského. ${ }^{45}$

Pojetí duchovní péče o nemocné v první české učebnici pastorální teologie bylo do určité míry odlišné. Profesor Chládek ve svých skriptech předložil jednotný ideální způsob péče o nemocné a umírající, bohatě doplněný konkrétními př́klady chování a promluv. Počítal se starou církevní svátostnou tradicí a pořádkem. Odkazoval také na tradiční literaturu určenou nemocným, mimo jiné na knihy o posledních čtyřech věcech člověka. ${ }^{46}$ Povinným tématem duchovní péče o nemocné bylo téma hř́chu. Jednotlivé úkony a obřady na sebe postupně navazovaly, každý nemocný a umírající se v duchu jednotné výuky měl bud' připravit na další křestansky ctnostný život, nebo zemřít zaopatřen posledními svátostmi. Na rovinu výchovy a vzdělávání byl ale i zde položen značný důraz. Poučování přitom neslo jasné christologické motivy. Duchovní pastýř přicházel za nemocným s útěchou, ta spočívala především v poznání správného pojmu nemoci. Ve své argumentaci mohl pastýř využít takzvaných důvodů pro potěšování nemocných, uvedených již v prvním díle učebnice. ${ }^{47}$ Svým př́stupem měl přivést nemocného $\mathrm{k}$ náhledu nemoci jako př́ležitosti a podnětu $\mathrm{k}$ dokonalejšímu křestanskému životu a ukázat mu i odpovídající konkrétní způsoby jednání. ${ }^{48}$

\section{Duchovní pastýŕ jako subjekt duchovní péče o nemocné a umírající}

Veškeré obsahy duchovní péče o nemocné představovaly podle zde analyzovaných učebních textů aktivity poučeného jednání a byly vyhrazeny správci duchovního úradu. Ten byl ve svém konání vázán př́islušnými pastýřskými normami a vzorci chování. Chládek ovšem ve své učebnici v souladu se staršími doporučeními výslovně připouštěl výjimku, ta ale měla jen omezený dosah. Duchovní správce mohl v případě svého zaneprázdnění pověřit i jiné osoby, a to i světské, aby v jeho zastoupení vykonaly návštěvu u lůžka nemocného. ${ }^{49}$ Ovšem subjektem péče zůstával i zde duchovní správce.

Duchovní pastýř měl zásadně přizpůsobit své konání potřebám nemocného a přicházet za ním jako dobrý př́tel s radou a pomocí, byt nevyžádanou. Vhodně měl vážit čas a nemocného nezatěžovat ve spánku a bolestech. Neslušelo se také, aby dával najevo strach, naopak si měl počínat odvážně, podobně jako jiní, kteří se také z lásky k bližnímu nebo vlasti často dostávali do ohrožení života. $Z$ řeči jeho úst i těla měl vyzařovat klid, rozvaha a jistota. Přitom ovšem měl předcházet nebezpečí a mít na paměti, že musí zachovat svůj

44 Srov. tamtéž, s. 254-255.

45 Srov. Gustav PIRICH, Franz Giftschütz, s. 196-197.

46 K duchovní literatuře se nemocný měl obracet především jako k prostředku pro posílení zbožnosti a využití času nemoci $\mathrm{k}$ svému dobru. Měl v ní hledat v duchu pastýřova př́stupu a vedení potěchu a poučení. Mezi touto duchovní literaturou byly výslovně jmenovány knihy o umučení Krista a o posledních čtyřech věcech člověka. Ačkoli se naposledy uvedené knihy př́ímo vztahovaly k onomu světu, toto téma duchovní pastýř sám od sebe neotvíral. Srov. Jiljí CHLÁDEK, Počátkové, II. díl, s. 156-158.

47 Srov. Jiljí CHLÁDEK, Počátkové, I. díl, s. 175-177.

48 Srov. Zdeněk DUDA, Nemoc a smrt v opatrné péči osvícenského pastýře, s. 59-66.

49 Srov. Jiljí CHLÁDEK, Počátkové, II. díl, s. 153-154. 
život pro sebe i pro svou obec. Bylo to důležité $\mathrm{z}$ hlediska obecného dobra, $\mathrm{z}$ hlediska státu i společnosti. Ctnostný život měl vyšší hodnotu než zbytečná a nerozvážná obět vyvolaná neznalostí nebo zanedbáním běžných prostř̌edků užívaných pro uchránění před hlavním zdrojem nákazy, za niž byly tehdy považovány různé nakažlivé výpary. ${ }^{50}$ Duchovní správce se $s$ př́klady těchto prostředků mohl seznámit př́́mo $\mathrm{v}$ učebnici, nebo pak rozsáhleji $\mathrm{v}$ odkazované literatuře, příznačně $\mathrm{z}$ protestantského prostředí. ${ }^{51}$ Moudré vyhodnocení svých možností a času vystupovalo do popředí v př́padě epidemií a moru, kdy bylo třeba prokázat co nejširšímu okruhu nemocných byt třeba jen tu nejnutnější péči. Současně bylo $\mathrm{v}$ takových situacích důležitým úkolem duchovního správce mírnit lidovou imaginaci, dodávat lidem odvahy a obecně i následováním př́ležitostných zvláštních nařízenía pravidel zabránit dalšímu šiření nákazy. ${ }^{52}$

Od duchovního pastýře se při péči o nemocné očekávalo mnohé, přitom se však vůbec nejednalo o jednoduchou oblast jeho aktivit. Řada lidí o jeho péči vlastně ani nestála, viděla $\mathrm{v}$ něm jen předzvěst a neodvratitelnost svého konce. Proto $\mathrm{k}$ péči o nemocné patřilo i úsilí o změnu smýšlení podstatné části veřejnosti. Péče o nemocné tak nezačínala návštěvou u lůžka nemocného, ale ideálně mnohem dříve na kazatelně nebo někde jinde při jiném způsobu veřejného i soukromého vyučování. $Z$ druhé strany pak $\mathrm{k}$ této péči také např́klad patřila starost o zaopatření chudých sirotků. ${ }^{53}$ Duchovní pastýr při péči o nemocné také nevystupoval pouze jako lékař duší a odborník na věci náboženské, ale jako všeobecný učitel a rádce, někdy i ve věcech vlastního lékařství, i jako garant veřejného pořádku a hygieny. Ve všem svém jednání měl být veden odvahou, ale i uměřeností v gestech a emocích, především však opravdovým přátelským zájmem o dobro konkrétních lidí i dobro obecné.

\section{Př́íprava na (dobrou) smrt}

Duchovní péče o nemocné byla často péčí o umírající osoby. Někdy se nemocný ke smrti blížil pozvolna, jindy náhle. Rozdílné okolnosti kladly rozdílné nároky na péči, júž se mu mělo dostat. Duchovní pastýr měl rozpoznat, v jaké situaci se nemocný právě nachází, a přizpůsobit tomu své konání. Někdy měl k dispozici vícero návštěv, jindy mohl počítat jen s jedinou a s časem navíc ještě omezeným a nejistým.

Giftschütz v nedostatku času doporučoval umírajícího krátce vyučit v základních náboženských otázkách a podle možnosti vyšetřit stav jeho duše, přitom ho ale nezatěžovat úplným vyznáním hř́íchů. Chládek pro stejnou situaci vyzýval duchovního pastýře, aby umírajíć́ho napomenul k vykonání zpovědi a přesvědčil ho k zaopatření dalšími posledními svátostmi. Pokud to čas dovoloval, mohl vybídnutí k pokání a vyznání hř́íchů spojit s výkladem a objasněním prospěšnosti a smyslu zpovědi, př́padně mu mohl také vymluvit

50 Srov. např. Daniela TINKOVÁ, Zákeřná mefitis. Zdravotní policie a veřejná bygiena v pozdně osvícenských Čechách, Praha: Argo, 2012.

51 Před nebezpečnými výpary mělo chránit vykouření octem, volba správného místa u hlavy nemocného, následně po návštěvě nemocného procházka ve větru a převlečení oděvu. $S$ dalšími vhodnými prostředky se budoucí duchovní správci mohli seznámit v knize Pierra Roquese o osobnosti evangelického faráře, odkazováno bylo na německý překlad. Srov. Franz GIFTSCHÜTZ, Počátkové, I. díl, s. 236-237. Chládek ve své učebnici vedle prostředků takzvaně přirozených (rovněž s odkazem na literaturu) uváděl i prostředky duchovní, mezi něž řadil modlitbu, naději a vložení se do vưle Boží. Srov. Jiljí CHLÁDEK, Počátkové, II. díl, s. $155-156$.

52 Srov. Franz GIFTSCHÜTZ, Počátkové, I. díl, s. 255-256.

53 Srov. tamtéž, s. 240. 
předsudky spojené s přijetím posledního pomazání. Dostávalo-li se umírajícímu času více, měl za ním duchovní pastýř přicházet opakovaně a prohloubit náboženskou výuku přinášející upokojení, potěchu a užitek pro př́pad smrti i uzdravení. ${ }^{54}$ Tento čas byl také vhodný k vyhotovení poslední vůle. Duchovní správci se měli omezit jen na obecná doporučení, umírající měli upomínat především na chudé, spoluúčast na tvorbě závěti jim byla dvorskými nařízeními značně omezena. ${ }^{55}$ Giftschütz také $\mathrm{v}$ duchu svého diferencovaného př́stupu a individualizované péče zvlášt pojednal otázku, jak jednat $s$ osobami, které ohrozily svůj život při pokusu o sebevraždu nebo život druhého člověka v souboji či bitce. ${ }^{56}$

Oba pastoralisté pak zavazovali duchovního pastýře strávit s umírajícím jeho poslední chvíle a napomoci mu poručit duši Bohu. Aby umírající nebyl ničím rozptylován a zatěžován, měli jeho nejbližší přenechat místo u lůžka duchovnímu a sami se vpovzdálí modlit za jeho duši. Giftschütz zde citoval vídeňský diecézní rituál..$^{57}$ Takováto praxe přisuzovala duchovnímu pastýři roli odborníka na věci tajemné a záhrobní a přes všechnu snahu o změnu ho potvrzovala $\mathrm{v}$ roli posla smrti. Racionální argumentace zde neměla sílu změnit prožitek fascinující a hrozivé moci lidskou představivostí asi nejvíce obsazeného přechodového rituálu. Chládkův požadavek, aby duchovní nebyl tím, kdo první nadnese téma smrti, ${ }^{58}$ př́padně Giftschützovo zvažování konkrétní situace, zda pravdu o blízké smrti vyslovit, či ne, ${ }^{59} \mathrm{zde}$ byly v naznačeném smyslu vlastně zbytečné.

Péče o umírající končila $\mathrm{v}$ př́padě smrti těšením a vzděláváním pozůstalých, $\mathrm{v}$ př́padě uzdravení povzbuzením k novému opravdovému křestanskému životu. Uzdravený člověk měl Bohu prokázat vděčnost za obdrženou milost navráceného zdraví, vzpomenout si na všechna svá předsevzetí učiněná $v$ době nemoci a splnit je. Duchovní správce měl rozpoznat, kde by u uzdraveného člověka mohlo hrozit nebezpečí nějakého zanedbání, a zabránit tomu, třeba předepsáním náležitého pořádku života. ${ }^{60}$ Uzdravený se totiž probudil do nového života, racionalizovaného, v němž konání bylo dáno věděním. Poznat znamenalo správně jednat a následně díky tomu svým př́kladem vzdělávat ostatní. Emociální složka a vždy do značné míry jedinečný prožitek životně významné situace, jakou bezpochyby byla blízkost smrti, nebyly - v dobovém osvícenském kontextu zcela pochopitelně - vůbec vzaty v úvahu. I když osvícenská duchovní péče o nemocné byla alespoň v učebnici vídeňského pastoralisty výrazně individualizována, vycházela z jednoduchých typizací a nebrala ohled na vnitřní prožívání, vůli a motivace objektu.

54 Srov. tamtéž, s. 249-250; Jiljí CHLÁDEK, Počátkové, II. díl, s. 159-160.

55 Chládek také odmítal tradiční zbožné odkazy jako ohavnost a jako výraz touhy po vlastním prospěchu a lakomství duchovních. Srov. Jiljí CHLÁDEK, Počátkové, II. díl, s. 176-178. Giftschütz věcně připomínal dvorská nařízení zakazující duchovním sepisovat závět druhým osobám. Srov. Franz GIFTSCHÜTZ, Počátkové, I. díl, s. 252-253.

56 Zatímco první osoby bylo třeba potěšit a ukázat jim svou spoluúčast a Boží slitovnou tvář, druhé bylo třeba bez okolků napomenout, ukázat jim směšnost představ o cti a přivést je k odpuštění a smíření. Srov. Franz GIFTSCHÜTZ, Počátkové, I. díl, s. 249-250. Chládek diferencuje mezi umírajícími v části, kde se věnuje otázce speciální způsobilosti pro přijetí svátosti posledního pomazání. Srov. Jiljí CHLÁDEK, Počátkové, II. díl, s. 180-183.

57 Srov. Franz GIFTSCHÜTZ, Počátkové, I. díl, s. 254-255; Jiljí CHLÁDEK, Počátkové, II. díl, s. 179-180.

58 Pastýř neměl nemocnému tajit nebezpečí smrti, nicméně ideálně měli o smrti jako první promluvit příbuzní anebo lékař. Srov. Jiljí CHLÁDEK, Počátkové, II. díl, s. 160.

59 Pastýř měl nejlépe učinit, pokud nemocného neujistil ani o uzdravení, ani o smrti. Giftschütz věděl, že někdy je lépe smrt na nějaký čas zatajit, jindy okamžitě přiznat. Vodítkem pro pastýře mělo být čtení konkrétní situace na základě tř́ kritérií: stavu těla a duše nemocného, jeho temperamentu a domácích specifik. Srov. Franz GIFTSCHÜTZ, Počátkové, I. díl, s. 251-252.

60 Srov. tamtéž, s. 255-256. 


\section{Závěr}

Reforma teologického studia provedená pod vlivem jansenisticko-osvícenských idejí $\mathrm{v}$ podunajské monarchii $\mathrm{v} 70$. letech 18 . století přinesla nové náhledy na osoby duchovních, z nichž se snažila vytvořit správce duchovenských úřadů. Studium získalo praktickou orientaci, která se odrazila i ve vzniku nové disciplíny pastorální teologie. Bohoslovci byli $\mathrm{v}$ jejím rámci systematicky připravováni na výkon duchovenské správy, obecně na výkon povinnosti poučovat, posvěcovat a podporovat zbožnost, samozřejmě v dobově správném výkladu, který $\mathrm{v}$ náboženské sfére akcentoval mravní oblast a propojoval pojem spásy s pojmy pozemského štěstí a obecného blaha. Součástí duchovenské správy byla i duchovní péče o nemocné a umírající, dobově nahlížená jako jedna z nejdůležitějších a současně nejobtížnějších aktivit duchovních správců. $V$ tomto smyslu se o ní vyjadřovala již Rautenstrauchova závazná osnova předmětu pastorální teologie. První dle ní vzniklé učebnice nového oboru tento náhled opakovaly. Duchovní péče o nemocné a umírající byla tehdy novinkou; spolu s pojmem nemoci jako místa do světa otevřených edukačních procesů překračovala a nahrazovala tradiční křestanskou př́pravu na dobrou smrt. Ztrácela také bezprostř̌ední vztah $\mathrm{k}$ svátostné praxi církve, výrazně např́íklad v dobově nejúspěšnější učebnici nového oboru od vídeňského pastoralisty Franze Giftschütze. Poslední pomazání zde pozbylo povahy svátosti a přestalo být (nutnou) součástí péče o umírající osoby. Tento přistup nebyl ojedinělý, ale na druhé straně ani výlučný. O několik let starší česky psaná učebnice Jiljího Chládka popisovala ideální obraz jednotné péče o nemocné a umírající, jejíž součástí byla i církevní svátostná tradice a pořádek posledních svátostí. Smyslem a cílem duchovní péče o nemocné a umírající bylo poskytnout lidem v tělesné a duševní nouzi útěchu a ponaučení, dodat jim pokoje a klidu a přivést je k polepšení. Tento cíl se nijak nelišil od cílů dalších aktivit duchovních správců. Prostředkem útěchy i poučení byl rozhovor, výklad, ale i modlitba, vždy zaměřená $\mathrm{k}$ Bohu, krátká a srozumitelná, reflektující konkrétní situaci nemocného. Důraz kladený $\mathrm{v}$ duchu osvícenského antropocentrismu na individualizovaný a diferencovaný př́stup k nemocným byl př́iznačný a typický především pro Giftschützovu učebnici. Podoba péče o nemocné a umírající se měla přizpůsobit konkrétní situaci a vycházet ze sociální př́slušnosti, vztahu k náboženství a druhu nemoci. Jediným uvažovaným subjektem této péče i všech dalších pastoračních aktivit byl správce duchovenského úradu. Jen výjimečně mohl být $\mathrm{v}$ této své úloze zastoupen. Ve svém konání byl vázán př́slušnými normami a vzorci chování, které se vztahovaly také na řeč úst i těla. Farní obec pak byla předmětem odpovídající poučené péče. Správce duchovenského úradu při péči o nemocné a umírající měl být učitelem a těšitelem, nabízet poučení přinášející užitek a radost $\mathrm{z}$ ctnostného života, stát se garantem veřejného pořádku a hygieny a zbavit se nálepky posla ohlašujícího smrt. Jako odborník na věci zásvětní a průvodce umíráním to však neměl lehké. I při realizaci duchovní péče o nemocné a umírající měl být, podobně jako ve všem svém dalším jednání, veden opravdovým přátelským zájmem o dobro konkrétního člověka i dobro obecné. 


\title{
Duchovní péče o nemocné a umírající v prvních učebnicích pastorální teologie (Rautenstrauch, Giftschütz, Chládek, Stach)
}

\begin{abstract}
Abstrakt
Příspěvek se soustředí na jednu z dějinných podob pastorace nemocných a umírajících. Zaměřuje se na konec 18. století, kdy pod vlivem jansenisticko-osvícenských idejí došlo k významné reformě teologického studia a zavedení pastorální teologie jako univerzitní disciplíny a kdy se pastorace nemocných a umírajících jako duchovní péče o nemocné začala profilovat coby jedna z nejvýznamnějších a nejdůležitějších oblastí aktivit duchovního pastýre jako jediného subjektu pastorace. Cílem príspěvku je na základě rozboru prvních učebních textů oboru pastorální teologie a kontextu, v němž byly sepisovány, popsat základní východiska, postupy a podobu duchovní péče o nemocné a umírající, jež byla jako ideální a závazná v rámci univerzitní výuky prezentována budoucím katolickým duchovním správcům. Studie se opírá především o dva učební texty, jež v českém prostředí došly širšího využití.
\end{abstract}

Klíčová slova: pastorace nemocných a umírajících, smrt, nemoc, 18. století, Franz Giftchütz, Jiljí (Aegidius) Chládek

\section{Spiritual Care of the III and the Dying in First Pastoral Theology Textbooks (Rautenstrauch, Giftschütz, Chládek, Stach)}

\begin{abstract}
The paper addresses one of the historic forms of pastoral care of the ill and the dying. It focuses on the end of the 18th century, when under the influence of Jansenist-enlightened ideas an important reform of theological study was carried out and pastoral theology was introduced as a university discipline, and when pastoral care of the ill and the dying as spiritual care of the ill came to be presented as one of the most significant and important sphere of the activities of the spiritual shepherd as the only subject of pastoral care. The aim of the paper is to describe the basic points of departure, procedures and form of spiritual care of the ill and the dying, which was as ideal and obligatory presented to future Catholic spiritual administrators as part of university study, based on analysis of the first study texts of the subject of pastoral theology and the context in which they were written. The study is based primarily on two study texts, which received wider use in the Czech milieu.
\end{abstract}

Keywords: pastoral care of the ill and the dying, death, illness, 18th century, Franz Giftchütz, Jiljí (Aegidius) Chládek

\section{Kontakt na autora}

\section{Mgr. et Mgr. Zdeněk Duda}

Jihočeská univerzita v Českých Budějovicích

Teologická fakulta, Katedra teologických věd

Kněžská 8, 37001 České Budějovice

Zdenek.Duda@seznam.cz 